\title{
PERKEMBANGAN KOGNITIF ANAK DALAM PERSFEKTIF PENDIDIKAN ISLAM
}

\author{
Suharnis
}

\begin{abstract}
Children's education begins from family (household) where they are influenced by what their parents do by imitating and learning. So, children's cognitive development is inseparable from the family environment. Children's development in cognitive theory shows the cognitive skills in the form of perception, learning process, attention, language skill, and emotion. These all are implicated in children's behavior regarding the cognitive development process in capturing, assessing, comparing, and responding to a stimulus before reacting. An individual receives a stimulus and then performs the cognitive process before reacting to the occurring stimulus. This process includes procedures for obtaining information, presenting, and transforming the information as knowledge. This knowledge reflects an indication of children's behavior and attitude. Therefore, children's cognitive development in psychological view is categorized into four: the sensorimotor stage, preoperational stage, concrete operational stage, and formal operational stage.
\end{abstract}

\section{Keywords: Cognitive Development, Children's, Islamic Education}

\section{PENDAHULUAN}

Sejak awal perkembangan pendidikan Islam telah berdiri tegak di atas dua sumber pokok yang amat penting yaitu Al-Quran dan sunnah Nabi. Di dalam kitab suci ini terkandung ayat-ayat mufasshalaat (terinci) dan ayat-ayat mubayyinat (yang memberikan bukti-bukti kebenaran) yang mendorong kepada orang untuk belajar membaca dan menulis serta untuk menuntut ilmu, memikirkan, merenungkan dan menganalisis ciptaan langit dan bumi. Oleh karena itu maka tujuan da'wah Islamiyah adalah untuk memberi cahaya terang kepada hati nurani dan pikiran serta menambah kemampuan umat Islam dalam melakukan proses pengajaran dan pendidikan. Karena 
171 | MUSA WA, Vol. 13 No.2 Desember 2021 : 170-202

Rasulullah s.a.w. sendiri diutus pertama-tama untuk menjadi pendidik dan beliau adalah guru yang pertama dalam Islam. ${ }^{1}$

Pendidikan Islam dimulai dari keluarga (rumah) di mana anak-anak menerima pengaruh dari apa yang dilakukan oleh kedua orang tuanya dengan cara meniru dan menerima pelajaran. Sembahyang merupakan pelajaran yang pertama-tama diberikan kepada anak sejak masa kecil, karena sembahyang itu merupakan salah satu rukun Islam yang kedua yang menjadi tiangnya agama. ${ }^{2}$

Pada hakikatnya agama Islam adalah agama yang mendasarkan kepada persamaan dan tasammuh (toleransi), kebebasan, kasih sayang antara sesama manusia, mengajarkan amar-ma'ruf dan nahi-mungkar. Dari aspek-aspek inilah pendidikan Islam berkembang dengan jiwa agama yang didasarkan pada rasa takut kepada Allah SWT; seorang muslim tidak ada yang ditakuti kecuali Allah SWT,dan ia berani menghadapi hak orang lain, yang telah ditetapkan berdasarkan sunnah Nabi dalam bentuk serta melaksanakan kewajiban menurut ajaran agamnya. Pendidikan Islam tidak dikenal pengertian interaksi seperti yang dikenal oleh para pemikir aliran empirisme- eksteralisme, akan tetapi pendidikan Islam mengenal adanya interaksi yang tidak mempertentangkan antara perbuatan seseorang yang berkaitan dengan hak-hak asasi terhadap kebebasan berkehendak (free will).

Perkembangan manusia tidak dapat dipisahkan dari pertumbuhannya. Pertumbuhan adalah sesuatu yang menyangkut materi jasmaniyah yang dapat menumbuhkan fungsi dan bahkan perubahan pada materi jasmaniah. Perubahan jasmaniah dapat menghasilkan kematangan atas fungsinya. Kematangan fungsi jasmaniah sangat mempengaruhi perubahan pada fungsi psikologis. Oleh karena itu,perkembangan manusia tidak dapat dipisahkan dengan pertumbuhannya. ${ }^{3}$

Pengaturan kegiatan kognitif merupakan kemahiran tersendiri. Orang yang memiliki kemampuan kognitif tinggi akan mampu mengontrol dan menyalurkan

\footnotetext{
${ }^{1}$ Moh.Daud Ali, Pendidikan Agama Islam, (Jakarta: Raja Grafindo, Persada, 2010), 383.

${ }^{2}$ Ibid, 400.

${ }^{3}$ Djaali, Psikologi Pendidikan, (Jakarta: Bumi Aksara, 2009), 21.
} 
aktifitas kognitif yang berlangsung dalam dirinya sendiri. Dalam menghadapi suatu problem dapat mengunakan berbagai strategi yang termasuk prosedural. Strategi ada yang dipakai secara luas dan ada yang terbatas. ${ }^{4}$ Sasaran belajar adalah pengaturan kegiatan kognitif dalam sistematika arus pikiran sendiri dan sistematisasi proses belajar dalam sendiri (control process). Untuk menunjuk pada pengaturan kegiatan kognitif dapat mengunakan metacognition yaitu pengaturan kegiatan kognititf dan belajar serta kontrol terhadap kegiatan itu pada diri sendiri. Yang harus dikuasai bukan hanya mengetahui apa bagaimana dan kapan harus berbuat (cognitive monitoring). Ada pun fase-fase jalur belajar pengaturan kegiatan kognitif adalah sebagai berikut yaitu, fase motivasi, fase konsentrasi, fase pengolahan, dan fase umpan balik. ${ }^{5}$

\section{Menurut Zakiah Darajat:}

Kepribadian seorang anak terbentuk menurut pengalaman an nilai-nilai yang diserapnya melalui dalam pertumbuhan dan perkembangannya terutama pada tahun pertama-tama umurnya apabila nilai agama banyak masuk keddalam pembentukan kepribadian seseorang maka tingkah laku seseorang tersebut akan banyak diarahkan oleh agama dan dikendalikan oleh nilai-nilai agama. Pengalaman-pengalaman dan nilai-nilai yang diserap oleh seorang anak diserap oleh seseorang melalui kognisi kemudian kemudian mengalami proses internalisasi sehingga dapat menimbulkan sikap dan perbuatan. ${ }^{6}$

Ranah psikologis yang paling baik dan terpenting adalah ranah kognitif. Ranah kejiwaan yang berkedudukan diotak ini dalam perfektif psikologi kognitif adalah adalah sumber sekaligus pengendali ranah-ranah kejiwaan lainya yaitu,ranah afektif (rasa),dan ranah psikomatorik (karsa).

Menurut Piaget proses belajar mengajar harus sesuai dengan tahapan kognitif yang dilalui siswa,sebab tingkah laku seseorang senantiasa didasarkan pada kognisi, yakni suatu tindakan mengenal atau memikirkan dimana suatu perilaku itu terjadi.

\footnotetext{
${ }^{4}$ Ibid., 67.

${ }^{5}$ Ibid, 68.

${ }^{6}$ Zakiah Daradjat, Pendidikan Islam dalam Keluarga dan Sekolah, (Bandung:
} Rosdakarya,1995), 62. 
173 | MUSA WA, Vol. 13 No.2 Desember 2021 : 170-202

Perkembangan inteligensi anak menurut piaget mengandung tiga aspek, yaitu structure, content, dan function. Adapun tahapan-tahapan perkembangan menurut Piaget ialah kematangan,pengalaman fisik atau lingkungan,transmisi sosial,dan equilibrium atau self regulation. Selanjutnya Piaget membagi tingkat perkembangan sebagai tahap sensori matorik, berpikir praoperasional, berpikir operasional kongkrit, dan berpikir operasional tunggal. ${ }^{7}$

Berdasarkan latar belakang masalah di atas, maka Penulis merasa tertarik untuk mengkaji dan melakukan penelitian lebih lanjut, tentang Perkembangan Kognitif Jean Piaget Ditinjau dari Persfektif pendidikan Islam, karena perkembangan kognitif adalah suatu cara yang digunakan oleh siswa dalam proses pembelajaran.

\section{PEMBAHASAN}

\section{Bentuk Perkembangan Anak dalam Tinjauan Teori Kognitif}

Psikologi kognitif merupakan salah satu cabang dari psikologi umum dan mencakup studi ilmiah tentang gejala-gejala kehidupan mental sejauh berkaitan dengan cara manusia berfikir dalam memperoleh pengetahuan,mengolah kesan-kesan yang masuk melalui indera, pemecahan masalah, mengali ingatan pengetahuan dan prosedur kerja yang di butuhkan dalam kehidupan sehari-hari. Kehidupan mental mencakup gejala kognitif, afektif, konatif sampai pada taraf tertentu, yaitu psikomatis yang tidak dapat di pisahkan secara tegas satu sama lain. Oleh karena itu, psikologi kognitif tidak hanya mengali dasar gejala khas kognitif tetapi juga dari afektif (penafsiran dan pertimbangan yang menyertai reaksi perasaan), konatif (putusan kehendak). Ilmu kognitif menjelaskan bidang penelitian psikologi yang mengurusi proses kognitif seperti perasaan, pengingatan, penalaran, pemutusan dan pemecahan masalah, serta menghindari adanya tumpang tindih ilmu pengetahuan yang tertarik dalam proses tersebut seperti filosofi. ${ }^{8}$

\footnotetext{
${ }^{7}$ Op.cit., 68.

${ }^{8}$ Djaali, Psikologi Pendidikan, 63.
} 
Psikologi kognitif adalah Adalah bidang studi psikologi yang mempelajari kemampuan kognisi, seperti: Persepsi, proses belajar, kemampuan memori, atensi, kemampuan bahasa dan emosi. Pendekatan kognitif menekankan bahwa tingkah laku adalah proses mental, dimana individu (organisme) aktif dalam menangkap, menilai, membandingkan, dan menanggapi stimulus sebelum melakukan reaksi. Individu menerima stimulus lalu melakukan proses mental sebelum memberikan reaksi atas stimulus yang datang.

Namun disisi yang lain ada juga yang berpendapat Psikologi kognitif adalah kajian studi ilmiah mengenai proses-proses mental atau pikiran. Proses ini meliputi bagaimana informasi diperoleh, dipresentasikan dan ditransfermasikan sebagai pengetahuan. Pengetahuan itu dimunculkan kembali sebagai petunjuk dalam sikap dan perilaku manusia. Oleh karena itu, psikologi kognitif juga disebut psikologi pemrosesan informasi. ${ }^{9}$ Dalam pandangan Piaget, terdapat dua proses yang mendasari perkembangan dunia individu, yaitu pengorganisasian dan penyesuaian. Untuk membuat dunia kita diterima oleh pikiran, kita melakukan pengorganisasian pengalaman-pengalaman yang telah terjadi. Piaget yakin bahwa kita menyesuaikan diri dalam dua cara yaitu asimiliasi dan akomodasi.

Ada dua konsep dasar psikologi kognitif, yaitu kognisi dan pendekatan kognitif yaitu: ${ }^{10}$

\section{Kognisi}

a. Kognisi Dalam istilah kognisi, maka psikologi kognitif dipandang sebagai cabang psikologi yang mempelajari proses-proses mental atau aktivitas pikiran manusia, misalnya proses-proses persepsi, ingatan, bahasa, penalaran dan pemecahan masalah.

b. Ingatan Kemampuan mengingat informasi dari membaca tentunya akan lebih lama dari hanya sekedar mendengar. Karena dengan membaca, pikiran atau otak kita

\footnotetext{
${ }^{9} \mathrm{http}: / /$ www.pak-sodikin.com/2011/12/9-ciri-ciri-dan-karakteristik-manusia.html.di akses 12 februari 2013

${ }^{10}$ Muhibin Syah, Psikologi Pendidikan Dengan Pendekatan Baru, ( Bandung: PT Remaja Rosdakarya, 2002) h.14-17
} 
175 | MUSA WA, Vol. 13 No.2 Desember 2021 : 170-202

akan bekerja lebih keras untuk memahami dan menyimpan informasi tersebut. Sedangkan dengan mendengar, kita hanya mengandalkan telinga, asalkan kita hafal. Bahkan kadang-kadang tanpa pemahaman.

c. Bahasa Informasi akan lebih mudah kita pahami dan kita mengerti, apabila bahasa yang digunakan sesuai dengan bahasa kita, maka informasi itu akan lebih maksimal kita gunakan. Karena otak atau pikiran kita mampu mencernaa inti informasi tersebut.

d. Penalaran Seseorang yang memiliki penalaran secara baik akan dapat memperoleh informasi yang berkaitan dengan masalah tersebut, tidak hanya dari satu sisi saja. Tapi dapat diperoleh dari bagian lain, karena suatu masalah biasanya yang hanya memiliki indikasi.

e. Persoalan Sikap dan perilaku manusia dapat mencerminkan masalah yang sedang dihadapi. Sikap dan perilaku ini, apabila digabungkan dengan informasi yang sudah ada, maka dapat menciptakan suatu solusi.

\section{Pendekatan Kognisi}

Sebagai suatu pendekatan maka psikologi kognitif dapat dipandang sebagai cara tertentu di dalam mendekati berbagai fenomena psikologi manusia. Konsep ini menekankan pada peran-peran persepsi, pengetahuan, ingatan, dan proses-proses berpikir bagi perilaku manusia.

a. Peran-Peran persepsi Orang yang berpersepsi atau berpikir bahwa kegagalan adalah sukses yang tertunda, dia akan selalu berusaha untuk mencoba lagi, walaupun dia ridak tahu kapan dia akan berhasil. Karena dipikirannya semakin dia mencoba, semakin banyak informasi yang didapat, maka tingkat kesalahan dapat diminimalisir atau dihindari. Hal ini menjadikannya sebagai pribadi yang sabar dan ulet.

b. Pengetahuan Orang yang banyak pengetahuan, biasanya lebih mengerti dan dapat mengelola informasi dengan cepat, karena dia tahu bagaimana cara mendapatkan informasi yang cepat, tepat, murah dan efisien. 
c. Proses-Proses Berpikir Jenjang pendidikan, lingkungan sekitar serta cara hidup mempengaruhi proses-proses dan pola berpikir kita. Orang yang berpendidikan tinggi, hidup di lingkungan berpendidikan dan cara hidup yang modern, biasanya akan mencari suatu informasi dengan cara yang berbasis teknologi yang lebih cepat dan praktis. Ini karena mereka telah dibentuk menjadi pribadi yang modern dengan cara berpikir yang cepat.

Prinsip dasar Psikologi Kognitif terbagi tiga bagian yaitu belajar aktif, belajar lewat interaksi sosial dan belajar lewat pengalaman sendiri. Dalam situasi belajar, seseorang terlibat langsung dalam situasi itu dan memperoleh "insight" untuk pemecahan masalah. ${ }^{11}$ Jadi kaum kognitif berpandangan, bahwa tingkah laku seseorang lebih bergantung insight terhadap hu bungan-hubungan yang ada di dalam situasi. Keseluruhan adalah lebih daripada bagian-bagiannya. Mereka memberi tekanan pada organisasin pengamatan atau stimulus di dalam lingkungan serta pada faktor-faktor yang mempengaruhi pengamatan.

Psikologi kognitif mulai berkembang dengan lahirnya teori belajar "gestalt". Peletak dasar psikiologi "gestalt" adalah Mex Wertheimer yang meneliti tentang pengamatan dan problem solving. Sumbangannya ini di ikuti oleh Kurt Koffka, yang menguraikan secara terperinci tentang hukum-hukum pengamatan, kemudian Wolfgang Kohler yang meneliti tentang insight pada simpanse. Penelitian-penelitian mereka menumbuhkan psikologi Gestalt yang menekankan bahasa pada masalah konfigurasi, struktur dan pemetaan dalam pengalaman. Kaum Gestaltis berpendapat, bahwa pengalaman itu berstruktur yang terbentuk dalam suatu keseluruhan. Orang yang belajar, mangamati stimulus dalam keseleruhan yang terorganisir, bukan dalam bagian-bagian yang terpisah. ${ }^{12}$ Tingakah kejelasan atau keberartian dari apa yang diamati dalam situasi belajar adalah lebih meningkatkan belajar seseorang daripada dengan hukuman dan ganjaran.

\footnotetext{
${ }^{11}$ M. Dalyono, Psikologi Pendidikan, (Jakarta: Rineka Cipta, 2010), 35.

${ }^{12}$ Ibid, 36.
} 
177 | MUSA WA, Vol. 13 No.2 Desember 2021 : 170-202

Aliran kognitif, menjelaskan belajar merupakan suatu proses internal yang tidak dapat di amati secara langsung. Perubahan tingkah laku seseorang tidak tampak sesungguhnya hanyalah refleksi dari perubahan internalisasi persepsi dirinya terhadap sesuatu yang sedang diamati dan dipikirkannya. ${ }^{13}$ Stimulus yang datang dari luar direspon sebagai aktivitas memori otak untuk membentuk dan mengembangkan struktur kognitif melalui proses asimilasi dan akomodasi yang kontinui, sehingga selalu ada hal yang memori dalam otak dalam setiap akhir kegiatan belajar. Menurut teori ini, ilmu pengetahuan dibangun dalam diri individu melalui proses interaksi yang berkesinambungan dengan lingkungan.

Ausebel adalah salah seorang aliran kognitif menyatakan, siswa akan belajar dengan baik jika apa yang di sebut kemajuan belajar didefinisikan dan dipresentasikan dengan baik dan tepat kepada siswa. Pengatur kemajuan adalah konsep atau informasi umum yang mencakup semua isi pelajaran yang akan diajarkan pada siswa. ${ }^{14}$ Proses belajar mengajar akan berjalan dengan baik jika seorang pendidik mampu memberi kesempatan pada siswanya untuk menemukan suatu konsep, informasi melalui contoh-contoh yang konkret.

Ahli teori kognitif memandang reinforcement (penguatan) sangat penting untuk umpan balik. Umpan balik ini memberi informasi tentang apa yang mungkin terjadi jika tingkah laku itu diulang. Terkait dengan penguatan maka pembiasaan dan keteladanan juga menjadi penting untuk usia anak sekolah, sehingga akan mampu terbentuk pribadi seperti apa yang biasa mereka amati dan perhatikan dalam kehidupannya.

Dalam proses pembelajaran tentunya memori maupun metode yang digunakan harus di sesuaikan dengan tingkat perkembangan siswa khusunya dalam perkembangan kognitifnya, karena tingkat berpikirnya berbeda-beda.

${ }^{13}$ Hamzah B. Uno, Orientasi Baru dalam Psikologi Pembelajaran, (Jakarta; Bumi Aksara,2006), 53.

14 Ibid, 12. 
Sasaran belajar adalah pengaturan kegiatan kognitif dalam sistematika arus pikiran sendiri dan sistematisasi proses belajar dalam diri sendiri (control process). Untuk menunjuk pada pengaaturan kegiatan kognitif dapat mengunakan metacognition, yaitu pengetahuan tentang kegiatan berpikir dan belajar serta kontrol terhadap kegiatan itu pada diri sendiri. Yang harus di kuasai bukan hanya mengetahui apa yang harus di perbuat melainkan juga mengetahui bagaimana dan kapan harus berbuat (cignitive monitoring). ${ }^{15}$ Adapun fase-fase atau jalur belajar pengaturan kegiatan kognitif terbagi atas, fase motovasi, fase konsentrasi, fase pengolahan, dan fase umpan balik.

\section{Pengaruh Perkembangan Anak dilihat dari Lingkungan Keluarga}

Pembahasan tentang perkembangan anak dalam pandangan Piaget adalah seorang psikolog “development" karena penelitiannya mengenai tahap-tahap perkembangan pribadi serta perubahan umur yang mempengaruhi kemampuan belajar individu. Dia adalah seorang psikolog yang suatu teori komprehensif tentang perkembangan intelegensinya atau proses berpikir. Menurut piaget, pertumbuhan kapasitas mental memberikan kemampuan-kemampuan mental baru yang sebelumya tidak ada. ${ }^{16}$

Piaget dalam teorinya memandang bahwa proses berpikir, sebagai aktivitas gradual dari fungsi intelektual dari konkret menuju abstrak, pertumbuhan intelektual adalah tidak kuantitatif, melainkan kualitatif. Piaget menyelediki masalah yang sama dari segi penyesuaian atau adaptasi manusia serta meneliti perkembangan intelektual atau kognisi berdasarkan dalil bahwa struktur intelektual terbentuk di dalam individu akibat interaksinya dengan lingkungan. ${ }^{17}$ Tujuan teori Piaget adalah untuk menjelaskan mekanisme dan proses perkembangan intelektual sejak masa bayi dan kemudian masa kanak-kanak yang berkembang menjadi seorang individu yang dapat bernalar dan berpikir menggunakan hipotesis-hipotesis.

\footnotetext{
${ }^{15}$ Djaali, Psikologi Pendidikan,(Jakarta: Bumi Aksara, 2009), 67.

${ }^{16}$ M. Dalyono, Psikologi Pendidikan, (Jakarta: Rineka Cipta, 2010), 39.

17 Ibid, 41.
} 
179 | MUSA WA, Vol. 13 No.2 Desember 2021 : 170-202

Ada tiga aspek perkembangan intelektual yaitu: struktur, isi dan fungsi. Struktur merupakan organisasi mental tingkat tinggi yang terbentuk pada individu waktu ia berinteraksi dengan lingkungannya. Isi merupakan pola perilaku khas anak yang tercermin pada responnya terhadap berbagai masalah atau situasi yang dihadapinya. Sedangkan fungsi adalah cara yang digunakan organisme untuk membuat kemajuan intelektual. Fungsi itu terdiri dari organisasi dan adaptasi. Semua organisme lahir dengan kecenderungan untuk beradaptasi atau menyesuaikan diri dengan lingkungan mereka.

Cara beradaptasi ini berbeda antara organisme yang satu dengan yang lain. Adaptasi terhadap lingkungan dilakukan melalui 2 proses yaitu: assimilasi dan akomodasi. Dalam proses asimilasi seseorang menggunakan struktur atau kemampuan yang sudah ada untuk menanggapi masalah yang dihadapinya dalam lingkungan. Dan proses akomodasi seseorang memerlukan modifikasi struktur mental yang ada untuk mengadakan respon terhadap tantangan lingkungan.

Piaget menyimpulkan dari penelitiannya bahwa organisme bukanlah agen yang pasif dalam perkembangan genetik. Perubahan genetik bukan peristiwa yang menuju kelangsungan hidup suatu organisme melainkan adanya adaptasi terhadap lingkungannya dan adanya interaksi antara organisme dan lingkungannya. Dalam responnya organisme mengubah kondisi lingkungan, membangun struktur biologi tertentu yang ia perlukan untuk tetap bisa mempertahankan hidupnya. Perkembangan kognitif yang dikembangkan Piaget banyak dipengaruhi oleh pendidikan awal Piaget dalam bidang biologi.

Hasil penelitiannya dalam bidang biologi, ia berkeyakinan bahwa suatu organisme hidup dan lahir dengan dua kecenderungan yang fundamental, yaitu kecenderungan untuk: ${ }^{18}$

a. Beradaptasi. Pada proses ini berisi dua kegiatan. Pertama, mengabungkan atau mengintegrasikan pengetahuan yang diterima oleh manusia atau disebut

${ }^{18}$ M. Dalyono, Psikologi Pendidikan, (Jakarta: Rineka Cipta, 2010), 56. 
asimilasi. Kedua, mengubah struktur pengetahuan yang sudah dimiliki dengan struktur pengetahuan baru, sehingga akan terjadi keseimbangan (equilibrium).

b. Organisasi (tindakan penataan). Yaitu proses ketika manusia menghubungkan informasi yang diterimanya dengan struktur-struktur pengetahuan yang sudah disimpan atau sudah ada sebelumnya dalam otak. Melalui proses ini, manusia dapat memahami sebuah informasi baru yang didapatnya dengan menyesuaikan informasi tersebut dengan struktur pengetahuan yang dimilikinya, sehingga manusia dapat mengasimilasikan atau mengakomodasikan informasi atau pengetahuan tersebut.

Untuk memahami proses-proses penataan dan adaptasi terdapat empat konsep dasar, yaitu sebagai berikut: ${ }^{19}$

a. Skema Istilah skema atau skemata yang diberikan oleh Piaget untuk dapat menjelaskan mengapa seseorang memberikan respon terhadap suatu stimulus dan untuk menjelaskan banyak hal yang berhubungan dengan ingatan.Skema adalah struktur kognitif atau serangkaian perilaku terbuka secara sistematis yang digunakan oleh manusia untuk mengadaptasi diri terhadap lingkungan (barang, orang, keadaan, kejadian) dan menata lingkungan ini secara intelektual. Misalnya, skema memegang adalah kemampuan umum untuk memegang sesuatu. Skema lebih dari sekedar manifestasi refleksi memegang saja. Skema memegang dapat dianggap sebagai struktur kognitif yang membuat semua tindakan memegang bisa dimungkinkan.Dalam teori Piaget, skema dianggap sebagai elemen penting dalam struktur kognitif organisme. Skema akan menentukan bagaimana ia akan merespon lingkungan fisik. Skemata dapat muncul dalam perilaku yang jelas, seperti dalam kasus refleks memegang, atau muncul secara tersamar. Manifestasi skema yang tidak jelas dapat disamakan dengan tindak berpikir. Jelas, cara anak menghadapi lingkungan akan berubah seiring dengan pertumbuhan anak. Agar terjadi

${ }^{19}$ Tim Penerbit Erlangga, Perkembangan Anak Edisi 20,(Jakarta: Erlangga, 2007), 247. 
181 | MUSA WA, Vol. 13 No.2 Desember 2021 : 170-202

interaksi organisme-lingkungan, skemata yang tersedia untuk anak harus berubah. Adaptasi terdiri atas proses yang saling mengisi antara asimilasi dan akomodasi

b. Asimilasi, Asimilasi yaitu suatu proses kognitif yang aktif dalam menggunakan skema untuk merespon lingkungan. Dengan asimilasi seseorang mengintegrasikan bahan-bahan persepsi atau stimulus ke dalam skema yang ada atau tingkah laku yang ada. Asimilasi berlangsung setiap saat. Seseorang tidak hanya memproses satu stimulus saja, melainkan memproses banyak stimulus. Secara teoritis, asimilasi tidak menghasilkan perubahan skemata, tetapi asimilasi mempengaruhi pertumbuhan skemata. Dengan demikian asimilasi adalah bagian dari proses kognitif, dengan proses itu individu secara kognitif mengadaptasi diri terhadap lingkungan dan menata lingkungan itu.

c. Akomodasi, Akomodasi dapat diartikan penyesuaian aplikasi skema yang cocok dengan lingkungan yang direspons. Atau sebagai penciptaan skemata baru atau pengubahan skemata lama. Asimilasi dan akomodasi terjadi samasama saling mengisi pada setiap individu yang menyesuaikan diri dengan lingkungannya. Proses ini perlu untuk pertumbuhan dan perkembangann kognitif. Antara asimilasi dan akomodasi harus ada keserasian dan oleh Piaget disebut sebagai keseimbangan

d. Keseimbangan Yaitu keseimbangan antara skema yang digunakan dengan lingkungan yang direspons sebagai hasil ketepatan akomodasi. Dalam proses adaptasi dengan lingkungan individu berusaha mencapai struktur mental atau skemata yang stabil. Yaitu keseimbangan antara proses asimilasi dan akomodasi. Seandainya hanya asimilasi secara kontiniu maka yang bersangkutan hanya akan memiliki beberapa skemata global dan ia tidak mampu melihat perbedaan antara berbagai hal. Sebaliknya jika hanya akomodasi saja secara kontinu, maka hanya memiliki skemata kecil-kecil saja dan mereka tidak memiliki skemata yang umum. Dan tidak akan mampu melihat persamaan antara berbagai hal. Dengan keseimbangan ini maka 
Suharnis, Perkembangan Kognitif ... 182

efisiensi interaksi antara anak yang sedang berkembang dengan lingkungannya dapat tercapai dan terjamin. Dengan kata lain terjadi keseimbangan antara faktor-faktor internal dan faktor eksternal. Proses akomodasi adalah proses memodifikasi struktur kognitif yang sudah dimiliki dengan informasi yang diterima.

Proses asimilasi dan akomodasi akan menimbulkan ketidakseimbangan antara yang telah diketahui dengan apa yang dilihat atau dialaminya sekarang. Proses ketidak seimbangan ini harus disesuaikan melalui proses ekuilibrasi. Proses ekuilibrasi ini merupakan proses yang berkesinambungan antara proses asimilasi dan akomodasi. Proses ini akan menjaga stabilitas mental dalam diri pembelajar dan ia akan dapat terus mengembangkan dan menambah pengetahuannya. Perubahan struktur kognitif yang dipengaruhi oleh proses adaptasi tersebut melalui tahap-tahap perkembangan tertentu sesuai dengan umurnya dan bersifat hierarki. Seseorang harus melalui urutan tertentu dan tidak dapat belajar sesuatu yang berada di luar tahap kognitifnya. ${ }^{20}$

Piaget membagi tahap-tahap perkembangan kognitif ini menjadi empat. Kemampuan bayi melalui tahapan ini bersumber dari tekanan biologis untuk menyesuaikan diri dengan lingkungan (melalui asimilasi dan akomodasi) serta adanya pengorganisasian struktur berpikir. Tahapan ini secara kualitatif berbeda pada setiap individu. Demikian pula, pemikiran seorang anak berbeda pada setiap tahap.

Untuk keperluan pengkonseptualisasian pertumbuhan kognitif dan perkembangan intelektual, Piaget membagi perkembangan ini ke dalam 4 periode yaitu: $:^{21}$

1) Periode Sensori motor (0,0-2,0 tahun)

Pada periode ini tingkah laku anak bersifat motorik dan anak menggunakan sistem penginderaan untuk mengenal lingkungannya untuk mengenal obyek.Tahap sensorimotor adalah yang pertama dari empat tahap perkembangan kognitif. "Pada

\footnotetext{
${ }^{20}$ Ibid, 249.

${ }^{21}$ Paul Suparno, Perkembangan Kognitif Jean Piaget, (Yogyakarta: Kanisius, 2006), 23.
} 
183 | MUSA WA, Vol. 13 No.2 Desember 2021 : 170-202

tahap ini, bayi membangun pemahaman tentang dunia dengan pengalaman panca indra koordinasi (seperti melihat dan mendengar) dengan fisik, motorik tindakan." "Bayi memperoleh pengetahuan tentang dunia dari tindakan-tindakan fisik yang mereka lakukan di atasnya." "Seorang bayi berkembang dari refleksif, insting tindakan saat lahir ke awal pemikiran simbolis menjelang akhir panggung."

Piaget membagi tahap sensorimotor menjadi enam sub-tahap Sub Tahap Usia Deskripsi Simple Refleks Kelahiran-6 minggu "Koordinasi sensasi dan aksi melalui perilaku refleksif'. Tiga dasar Reflek yang dijelaskan oleh Piaget: mengisap bendabenda di mulut, berikut obyek bergerak atau menarik dengan mata, dan penutupan tangan ketika membuat sebuah objek kontak dengan telapak (palmaris pegang). Selama enam minggu pertama kehidupan, refleks ini mulai menjadi tindakan sukarela, misalnya refleks menjadi palmaris sengaja menangkap.

Anak menggunakan reflek alamiah, dan mengikuti gerakan objek dalam medan penglihatan reaksi sirkular primer 6 minggu-4 bulan "Koordinasi sensasi dan dua jenis skema: kebiasaan (refleks) dan reaksi sirkular primer (reproduksi dari sebuah peristiwa yang awalnya terjadi secara kebetulan). Utama masih fokus pada tubuh bayi." Sebagai contoh jenis reaksi, bayi mungkin akan mengulangi gerakan lewat tangan mereka sebelum wajah mereka. Juga pada tahap ini, reaksi pasif, yang disebabkan oleh klasik atau instrumental conditioning. Contohnya, sekiranya bayi tersebut melakukan sesuatu tingkah laku yang mana dapat menyenangkan dia, maka dia akan mengulangi tingkah laku itu lagi. Dan anak terus memandangi objek yang hilang.

Fase reaksi sirkular sekunder 4-8 bulan Pengembangan kebiasaan. "Bayi menjadi lebih object-oriented, bergerak di luar keasyikan diri; ulangi tindakan yang membawa hasil yang menarik atau yang menyenangkan." Tahap ini terutama berhubungan dengan pengembangan koordinasi antara visi dan kemampuan memegang. Tiga kemampuan baru terjadi pada tahap ini, disengaja menggapai untuk objek yang dikehendaki, reaksi sirkular sekunder, dan pembedaan antara tujuan dan sarana. Pada tahap ini, bayi akan sengaja menangkap udara ke arah objek yang 
dikehendaki, sering membuat geli teman-teman dan keluarga. Reaksi sirkular sekunder, atau pengulangan dari suatu tindakan yang melibatkan objek eksternal mulai misalnya, memindahkan saklar untuk menyalakan lampu berulang-ulang.

Pembedaan antara cara dan tujuan juga terjadi. Ini mungkin salah satu yang paling penting pada tahap-tahap pertumbuhan anak karena menandakan fajar logika. Dan anak mencari objek yang hilang.Koordinasi tahap reaksi sirkular sekunder 8-12 bulan "Koordinasi visi dan sentuhan - koordinasi tangan-mata; koordinasi skema dan niat." Tahap ini terutama terkait dengan perkembangan logika dan koordinasi antara sarana dan tujuan. Ini adalah sangat penting pada tahap perkembangan, Piaget memegang apa yang disebutnya "tepat pertama kecerdasan." Selain itu, tahap ini menandai awal orientasi tujuan, perencanaan yang disengaja dan langkah-langkah untuk memenuhi suatu tujuan. Anak mulai menggunakan tanda untuk mengantisipasi kejadian, mengenali objek dan orang yang sudah dikenal dan mencari objek yang di sembunyikan.

Reaksi sirkular tersier, kebaruan, dan rasa ingin tahu 12-18 bulan "Bayi menjadi tergelitik oleh banyak sifat-sifat benda dan oleh banyak hal yang mereka dapat membuat terjadi pada objek; mereka bereksperimen dengan perilaku baru.” Tahap ini berhubungan terutama dengan penemuan cara-cara baru untuk memenuhi tujuan menggunakan trial and error. Piaget menjelaskan anak pada saat ini sebagai "ilmuwan muda," melakukan pseudo-eksperimen untuk menemukan metode baru menghadapi tantangan. Mencari objek yang disembunyikan dan meniru tindakan orang lain.

Internalisasi Skema 18-24 bulan "Bayi mengembangkan kemampuan untuk menggunakan simbol-simbol dan bentuk primitif bertahan lama mental." Tahap ini berhubungan terutama dengan awal pemahaman, atau kreativitas. Mengembangkan kemampuan menirukan, mengembangkan citra mental untuk menyelesaikan masalah, mengantisipasi konsekuensi, menngetahui objek tetap ada setelah objek hilang dari pandangan. 
185 | MUSA WA, Vol. 13 No.2 Desember 2021 : 170-202

Menurut Piaget pada akhir dari periode sensorimotor, objek keduanya terpisah dari diri dan permanen. Objek keabadian adalah pemahaman bahwa benda tetap ada bahkan ketika mereka tidak dapat dilihat, didengar, atau disentuh. Mendapatkan pengertian objek permanen adalah salah satu prestasi bayi yang paling penting.

2) Periode Pra operasional (2,0-7,0 tahun)

Pada periode ini anak bisa melakukan sesuatu sebagai hasil meniru atau mengamati sesuatu model tingkah laku dan mampu melakukan simbolisasi. Piaget juga mengatakan bahwa proses perkembangan kognitif kanak-kanak menjadi lebih sempurna menerusi "tiga kebolehan azas" yang berlaku yaitu :

a. Perkembangan kebolehan mental kanak-kanak untuk melakukan tingkah laku yang ketara seperti kebolehan mengira. Melalui latihan yang diulang-ulang, rangkaian tingkah laku yang dikukuhkan dan digeneralisasikan sehingga menjadi skema tingkah laku yang stabil. Hal-hal umum yang betul-betul difahami oleh individu bagi mewujudkan sesuatu pengukuhan tingkah laku.Selain itu, Piaget juga mengatakan bahwa operasi yang berlaku mesti berasaskan pada tiga fenomena mental yang penting yaitu pengamatan, ingatan dan bayangan.

b. Pengamatan merupakan suatu proses dimana kanak-kanak memberikan sepenuh perhatian terhadap sesuatu yang dilihat. Sementara, ingatan pula ialah satu proses pembinaan, pengumpulan dan pengambilan kembali memori mengenai peristiwa lalu. Sedangkan, bayangan merupakan satu proses yang menyebabkan sensasi yang statik, yang mana pandangan dan pendengaran selalu dikumpulkan di bagian mental.Yang sebelum operasi tahap kedua dari empat tahap perkembangan kognitif. Dengan mengamati urutan permainan, Piaget mampu menunjukkan bahwa menjelang akhir tahun kedua, yang secara kualitatif jenis baru dari fungsi psikologis terjadi. (Pre) Operatory Pikiran adalah setiap prosedur untuk bekerja pada objek mental. Ciri dari tahapan yang jarang dan secara logika tidak memadai operasi 
mental. Selama tahap ini, anak belajar menggunakan dan merepresentasikan objek dengan gambar, kata, dan gambar. Si anak mampu membentuk konsepkonsep yang stabil serta penalaran mental dan keyakinan magis. Namun anak masih belum mampu melakukan operasi; tugas yang si anak dapat melakukan mental daripada fisik. Berpikir anak masih egosentris dan anak kesulitan mengambil sudut pandang orang lain.

Dua substages dapat dibentuk dari pikiran sebelum operasi yaitu :

a. The Symbolic Fungsi Substage

Terjadi antara rentang usia 2 dan 4 . Si anak mampu merumuskan desain benda-benda yang tidak hadir. Contoh lain dari bahasa kemampuan mental dan berpura-pura bermain. Walaupun ada kemajuan, masih ada keterbatasan seperti egocentrism dan animisme.

Egocentrism terjadi ketika seorang anak tidak mampu membedakan antara perspektif mereka sendiri dan orang lain. Anak-anak cenderung memilih pandangan mereka sendiri apa yang mereka lihat daripada tampilan sebenarnya ditampilkan ke orang lain. Salah satu contoh adalah eksperimen dilakukan oleh Piaget dan barbel Inhelder. Tiga dilihat dari sebuah gunung yang ditampilkan dan si anak diminta apa boneka keliling akan melihat pada berbagai sudut; anak mengambil pandangan mereka sendiri dibandingkan dengan pandangan aktual boneka.

Animisme adalah kepercayaan bahwa benda-benda mati mampu bertindak seperti manusia hidup dan memiliki kualitas. Contohnya adalah seorang anak percaya bahwa trotoar gila dan membuat mereka jatuh bawah.

b. Pikiran yang intuitif Substage

Terjadi antara rentang usia 4 dan 7. Anak-anak cenderung menjadi sangat ingin tahu dan mengajukan banyak pertanyaan; mulai menggunakan penalaran primitif. Ada kemunculan untuk kepentingan penalaran dan ingin tahu mengapa halhal terjadi.

Piaget menyebutnya intuitif substage karena anak-anak menyadari bahwa mereka memiliki sejumlah besar pengetahuan tetapi mereka tidak mengetahui 
187 | MUSA WA, Vol. 13 No.2 Desember 2021 : 170-202

bagaimana mereka tahu itu. Centration dan konservasi keduanya terlibat dalam berpikir sebelum operasi.

Centration adalah tindakan memusatkan seluruh perhatian pada satu karakteristik dibandingkan dengan yang lain. Centration adalah memperhatikan konservasi; kesadaran bahwa mengubah penampilan suatu zat tidak merubah sifat dasar. Anak-anak pada tahap ini tidak menyadari konservasi. Dalam penelitian Piaget, seorang anak dihadapkan dengan dua gelas berisi jumlah cairan yang sama. Si anak biasanya mencatat bahwa gelas memiliki jumlah cairan yang sama.

Ketika salah satu dari gelas dituangkan ke dalam kontainer yang lebih tinggi dan kurus, anak-anak yang biasanya lebih muda dari 7 atau 8 tahun mengatakan bahwa sekarang dua gelas berisi jumlah cairan yang berbeda. Si anak hanya berfokus pada tinggi dan lebar wadah dibandingkan dengan konsep umum.

Piaget percaya bahwa jika seorang anak gagal dalam tugas konservasi-of-cair, itu merupakan tanda bahwa mereka berada pada tahapan perkembangan kognitif. Anak juga gagal untuk menunjukkan konservasi angka, materi, panjang, volume, dan luas. Contoh lain adalah ketika seorang anak melihat 7 anjing dan 3 kucing di layar dan bertanya apakah ada lebih anjing daripada kucing? Anak akan merespons secara positif. Namun ketika ditanya apakah ada lebih anjing daripada hewan, anak akan kembali merespon positif.

Seperti kesalahan mendasar dalam logika menunjukkan transisi antara intuitif dalam memecahkan masalah dan penalaran logis sejati diperoleh di tahun-tahun berikutnya ketika anak tumbuh.Piaget menganggap bahwa anak-anak terutama belajar melalui imitasi dan bermain selama dua tahap pertama ini, ketika mereka membangun gambar simbolis melalui kegiatan diinternalisasi

Jika orang dewasa tidak mendapatkan konsep ini, mereka tidak akan dapat memahami sudut pandang lain orang. Mungkin ada perbedaan dalam komunikasi antara eksperimen dan anak-anak yang mungkin telah mengubah hasil. Ia juga telah menemukan bahwa jika konservasi tidak secara luas di negara tertentu, konsep dapat diajarkan kepada anak dan pelatihan dapat meningkatkan pemahaman anak. Oleh 
karena itu, diketahui bahwa terdapat perbedaan umur yang berbeda dalam mencapai pemahaman tentang konservasi didasarkan pada sejauh mana budaya mengajarkan tugas-tugas ini.

3) Periode konkret (7,0-11,0 tahun)

Pada periode ini anak sudah mampu menggunakan operasi. Pemikiran anak tidak lagi didominasi oleh persepsi, sebab anak mampu memecahkan masalah secara logis. Tahap operasional konkrit adalah yang ketiga dari empat tahap perkembangan kognitif dalam teori Piaget. Tahap ini, yang mengikuti tahap praoperasional, terjadi antara usia 7 dan 11 tahun dan ditandai oleh penggunaan yang sesuai logika.

Proses penting selama tahap ini adalah:

1. Pengurutan; kemampuan untuk menyortir benda-benda dalam urutan sesuai dengan ukuran, bentuk, atau ciri lainnya. Sebagai contoh, bila diberi benda berbeda ukuran mereka mungkin membuat warna gradien.

2. Transitivitas; Kemampuan untuk mengenali hubungan logis di antara unsurunsur dalam urutan serial, dan melakukan 'transitif kesimpulan' (misalnya, Jika A lebih tinggi daripada B, dan B lebih tinggi daripada C, maka A harus lebih tinggi dari C).

3. Klasifikasi; kemampuan untuk memberi nama dan mengidentifikasi serangkaian benda menurut tampilannya, ukuran atau karakteristik lain, termasuk gagasan bahwa serangkaian benda-benda dapat menyertakan lain.

4. Decentering; anak mulai mempertimbangkan beberapa aspek dari suatu permasalahan untuk bisa memecahkannya. Misalnya, anak tidak akan lagi menganggap luar biasa cangkir lebar tapi pendek untuk mengandung kurang dari normal-lebar, tinggi cangkir.

5. Kedapatbalikan; anak memahami bahwa jumlah atau benda-benda dapat diubah, kemudian kembali ke keadaan awal. Untuk alasan ini, seorang anak akan dapat dengan cepat menentukan bahwa 4+4 sama dengan t, t-4 akan sama dengan 4, jumlah sebelumnya. 
189 | MUSA WA, Vol. 13 No.2 Desember 2021 : 170-202

6. Konservasi; memahami bahwa kuantitas, panjang, atau jumlah benda-benda adalah tidak berhubungan dengan pengaturan atau tampilan dari objek atau item.

7. Penghapusan Egocentrism; kemampuan untuk melihat sesuatu dari perspektif lain (bahkan jika mereka berpikir salah). Sebagai contoh, tunjukkan komik seorang anak di mana Jane meletakkan boneka di bawah kotak, meninggalkan ruangan, dan kemudian Melissa menggerakkan boneka ke laci, dan Jane kembali. Seorang anak dalam tahap operasi konkrit akan mengatakan bahwa Jane akan tetap berpikir itu di bawah kotak meskipun anak tahu itu adalah di dalam laci. Anak-anak di tahap ini bisa, bagaimanapun, hanya memecahkan masalah-masalah yang berlaku untuk obyek atau peristiwa aktual, dan bukan konsep-konsep abstrak atau hipotetis tugas.

8. Reversibilitas; anak berfikir bahwa adonan pipih bisa dibentuk kembali menjadi bola

9. Anak mengembangkan empati atas posisi atau kedudukan orang lain. Kemampuan dalam konsentrasi, perhatian dan memori lebih besar.

4) Periode operasi formal (11 - dewasa)

Periode operasi fomal merupakan tingkat puncak perkembangan struktur kognitif, anak remaja mampu berpikir logis untuk semua jenis masalah hipotesis, masalah verbal, dan ia dapat menggunakan penalaran ilmiah dan dapat menerima pandangan orang lain. Perkembangan kognitif pada peringkat ini merupakan ciri perkembangan remaja dan dewasa yang menuju ke arah proses berfikir dalam peringkat yang lebih tinggi. Peringkat berfikir ini sangat diperlukan dalam pemecahan masalah.

Piaget mengemukakan bahwa ada 4 aspek besar yang ada hubungannya dengan perkembangan kognitif $:^{22}$

${ }^{22}$ Ibid. 40 
a) Pendewasaaan/kematangan, merupakan pengembangan dari susunan syaraf. Pada aspek ini penalaran orang dewasa semakain berkembang, karena mereka lebih berpengalaman dan banyak belajar. Mereka dapat berpikir tentang sesuatu melalui proses berpikir logis dan abstraksi yang lebih kaya. Dengan meningkatnya usia, seseorang menjadi lebih memahami berbagai konsep abstrak, seperti keadilan, kebenaran dan hak asasi. Mereka juga telah dapat menimba pengalaman dari berbagai konflik yang terjadi sebelumnya karena terjadinya individuasi selama masa transisi dari anak-anak menuju masa dewasa.

b) Pengalaman fisis, anak harus mempunyai pengalaman dengan benda-benda dan stimulus-stimulus dalam lingkungan tempat ia beraksi terhadap bendabenda itu.

c) Interaksi sosial, adalah pertukaran ide antara individu dengan individu

d) Keseimbangan, adalah suatu sistem pengaturan sendiri yang bekerja untuk menyelesaikan peranan pendewasaan, pengalaman fisis, dan interaksi sosial.

Di seluruh sejarah psikologi,hanya sedikit saja teorisi yang mencapai posisi sepenting Jean Piaget (1896-1980), yang membuat sebuah teori tentang perkembangan intelektual paling komprehensif dan mendekati kebenaran.

Teori Piaget adalah kisah terpadu yang menjelaskan bagaimana faktor biologis dan pengalaamn membentuk perkembangan kognitif. Piaget berpikir sebagaimana tubuh fisik kita memiliki struktur yang memampukan kita beradaptasi dengan dunia, struktur-struktur mental juga membantu kita beradaptasi dengan dunia. Adaptasi meliputi penyesuain terhadap tuntutan-tuntutan baru dari lingkungan. ${ }^{23}$

Piaget percaya bahwa pemikiran anak-anak berkembang menurut tahap-tahap atau periode-periode yang terus bertambah kompleks. Menurut teori tahapan Piaget, setiap individu akan melewati serangkaian perubahan kualitatif yang bersifat invariant, selalu tetap, tidak melompat atau mundur. Perubahan kualitatif ini terjadi

\footnotetext{
${ }^{23}$ Tim Penarbit Erlangga,Perkembangan Anak Edisi 20, (Jakarta; Erlangga,2007) h. 243
} 
191 | MUSA WA, Vol. 13 No.2 Desember 2021 : 170-202

karena tekanan biologis untuk menyesuaikan diri dengan lingkungan serta adanya pengorganisasian struktur berfikir.

\section{Perkembangan Anak Ditinjau dari Persfektif Pendidikan Islam}

Islam adalah agama yang menempatkan pendidikan dalam posisi yang sangat vital. Bukanlah suatu kebetulan jika ayat pertama Al-Quran, surat al-'Alaq memulai dengan perintah membaca, iqra'. Di samping itu, pesan-pesan Al-Qur'an dalam hubungannya dengan pendidikanpun dapat dijumpai dalam berbagai ayat dan surat dengan aneka ungkapan pernyataan, pertanyaan dan kisah. Lebih khusus lagi, kata ilm dan derivasinya digunakan paling dominan dalam Al-Qur'an untuk menunjukkan perhatian Islam yang luar biasa terhadap pendidikan.

Al-Qur'an merupakan sumber pendidikan dan ilmu pengetahuan yang mengajarkan manusia dengan bahasanya yang lemah lembut, balaghoh yang indah, sehingga al-Qur'an membawa dimensi baru terhadap pendidikan dan berusaha mengajak para ilmuwan untuk menggali maksud kandungannya agar manusia lebih dekat kepada-Nya.

Petunjuk pendidikan dalam al-Qur'an tidak terhimpun dalam kesatuan pragmen tetapi ia diungkapkan dalam berbagai ayat dan surat al-Qur'an, sehingga untuk menjelaskannya perlu melalui tema-tema pembahasan yang relevan dan ayatayat yang memberikan informasi-informasi pendidikan yang dimaksud.

Merujuk kepada informasi al-Qur'an pendidikan mencakup segala aspek jagat raya ini, bukan hanya terbatas pada manusia semata, yakni dengan menempatkan Allah sebagai Pendidik Yang Maha Agung. Konsep pendidikan al-Qur'an sejalan dengan konsep pendidikan Islam yang dipresentasikan melalui kata tarbiyah, ta'lim dan ta'dib. ${ }^{24}$

\footnotetext{
${ }^{24}$ Bukhari Umar, Ilmu Pendidikan Islam,(Jakarta; Amzah, 2011).h.21
} 
Dari beberapa istilah yang digunakan bahwa pendidikan Islam adalah rangkaian proses transformasi dan internalisasi ilmu pengetahuan dan nilai-nilai pada anak didik melalui pertumbuhan dan pengembangan potensi fitrahnya, baik aspek spiritual, intelektual, maupun fisiknya, guna keselarasan dan kesempurnaan hidup dalam segala aspeknya sesuai dengan nilai-nilai ajaran Islam. Batasan di atas, memberikan gambaran bahwa, eksistensi pendidikan merupakan sarana vital dalam upaya menumbuh kembangkan daya kreativitas anak didik, melestarikan nilai-nilai ilahiyah dan insaniyah, serta membekali anak didik yang produktif yang memungkinkan anak didik dapat hidup sesuai dengan perkembangan lingkungan dimana ia berada. ${ }^{25}$

Akal adalah karunia Allah Swt. yang besar bagi manusia. Agama Islam berisi pedoman bagi manusia yang berakal. Hanya manusia yang berakal saja yang dapat mengambil pelajaran dari penciptaan langit dan bumi.Pembinaan pola pikir/kognitif, yakni pembinaan kecerdasan dan ilmu pengetahuan yang luas dan mendalam sebagai penjabaran dari sifat fathonah Rosulullah. Seseorang yang fathonah itu tidak hanya cerdas, tetapi juga memiliki kebijaksanaan atau kearifan dalam berpikir dan bertindak. Mereka yang mempunyai sifat fathonah mampu menangkap gejala dan hakikat dibalik semua peristiwa. Mereka mampu belajar dan menangkap peristiwa yang ada di sekitarnya, kemudian menyimpulkannya sebagai pengalaman berharga dan pelajaran yang memperkaya khazanah. Mereka tidak segan untuk belajar dan mengajar, karena hidup hanya semakin berbinar ketika seseorang mampu mengambil pelajaran dari peristiwa-peristiwa tersebut.

Para psikolog kognitif menaruh banyak perhatian pada berbagai macam persoalan dengan menggunakan kemampuan berpikir secara efisien dan efektif. Sasaran dari belajar pengaturan kegiatan kognitif adalah sistematisasi proses belajar dalam diri sendiri. Dalam psikologi modern sistematisasi dan pengaturan kegiatan mental yang kognitif ini dipandang sebagai suatu proses kontrol (control procces).

\footnotetext{
${ }^{25}$ Ibid,,h.35-36
} 
193 | MUSA WA, Vol. 13 No.2 Desember 2021 : 170-202

Kognitif adalah kemampuan berpikir yang berpusat di otak ini berfungsi untuk menerima, mengolah dan menginterpretasikan pengetahuan-pengetahuan dan pengalaman yang di peroleh melalui interaksi lingkungan.

Berpikir tidak bisa di pisahkan dengan akal sebagai tempat untuk berpikir, dalam Islam telah di jelaskan bahwa yang membedakan manusia dengan mahluk lainnya adalah terletak pada akalnya. Oleh sebab itu potensi akal (kognisi) seseorang sangat berharga dan perlu di arahkan kepada hal yang positif agar kepribadian yang di timbulkan jga positif. Sebab kepribadian seseorang dipengaruhi oleh konsep berpikirnya.

Ajaran Islam akal (kognisi) sangat dijunjung tinggi, akan tetapi akal pikiran manusia sangat terbatas hal ini berpengaruh pada pengetahuan yang diperolehnya juga akan terbatas sehingga dengan pengetahuan manusia akan sulit memecahkan segala persoalan yang ada. ${ }^{26}$ Maka dari hal itu akal (kognisi) perlu arahan dan perlu dikembangkan yakni dengan berbagai hal seperti melalui pendidikan dan lain sebagainya agar pengetahuan seseorang semakin luas dan mendalam. Dalam pendidikan pengembangan akal merupakan hal yang utama dan hal ini sangat berpengaruh terhadap pengembangan sikap dan kepribadian.

Psikologi perkembangan dalam Islam merupakan kajian atas proses pertumbuhan dan perubahan manusia yang menjadikan Al-qur'an dan Hadits sebagai landasan pikirannya.Psikologi perkembangan dalam Islam adalah perkembangan manusia tersebut meliputi proses pertumbuhan atau perubahan manusia serta membahas berbagai aspek perkembangan yang meliputi: aspek perkembangan fisik, kognitif, emosional, moral, social, spiritual, dan lain-lain.

Secara global fase perkembangan kognitif menurut Ibnu Jauzi dapat ditelaah dengan pemahaman konsep ketuhanan,klasifikasi fase ini di ambil dari ayat-ayat Alquran , yang dalam hal ini terbagi menjadi beberapa fase, yaitu: ${ }^{27}$

${ }^{26}$ Zahrudin, dkk, Pengantar Studi Akhlak, (Jakarta: Grafindo, 2004), 51.

27 Abdul Malik Karim Amrullah, Jurnal Psikologi Vol.V. No. 1.Fase Motif Beragama Menurut Islam. (Malang; Universitas Islam Negeri Malang Press,2008). 6. 
1. Fase anak-anak

Fase anak-anak mempunyai perilaku yang unik ketika mereka memaknai Tuhan. Mereka memaknai Tuhan seperti manusia yang super hebat dan bisa menolong mereka dalam keadaan apapun. Karena pada fase ini anak-anak akan mengfungsikan nalar pendengarnya yang belum bisa memberikan arahan pada proses penyadaran terhadap objek secara mendalam. Kemudian nalar inderawinya mulai berfungsi ketika nalar pendengarannya sudah mulai berfungsi ,dari nalar inderawi inilah mulai terjadi proses penyadaran terhadap objek yang di serap oleh anak. Setelah nalar batin (intiutif) yang merupakan pintu gerbang pengenalan anak tehadap Tuhan sebagaimana yang terdapat dalam Surat Al-an'am ayat 78, yaitu:

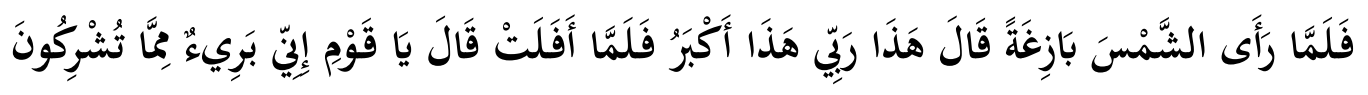

Terjemahnya: "Kemudian tatkala dia melihat matahari terbit, dia berkata: "Inilah Tuhanku, ini yang lebih besar", maka tatkala matahari itu telah terbenam, dia berkata: "Hai kaumku, sesungguhnya aku berlepas diri dari apa yang kamu persekutukan.’(Q.S. AlAn'am:78) $)^{28}$

Sifat agama pada anak tumbuh mengikuti ideas concept on outority, hal ini sesuai dengan ciri yang mereka miliki, ide keagamaan pada anak hampir sepenuhnya outoritas, maksudnya konsep keagamaan mereka dipengaruhi oleh faktor dari luar diri mereka. Hal tersebut dapat dimengerti kerena sejak usia muda telah melihat, mempelajari hal-hal yang dikerjakan dan diajarkan oleh orang tua atau orang dewasa di sekitarnya tentang pemahaman keagamaan.

2. Fase remaja.

Perkembangam kognitif pada fase remaja oleh Ismail dapat dilihat yang mampu mengembangkan pemahaman keagamaanya dengan pemahaman yang setingkat lebih tinggi dari putra-putra Nabi Ya'qub. Dijelaskan dalam surat AsShaffat ayat 102:

\footnotetext{
${ }^{28}$ Departemen Agama, RI, ....
} 
195 | MUSA WA, Vol. 13 No.2 Desember 2021 : 170-202

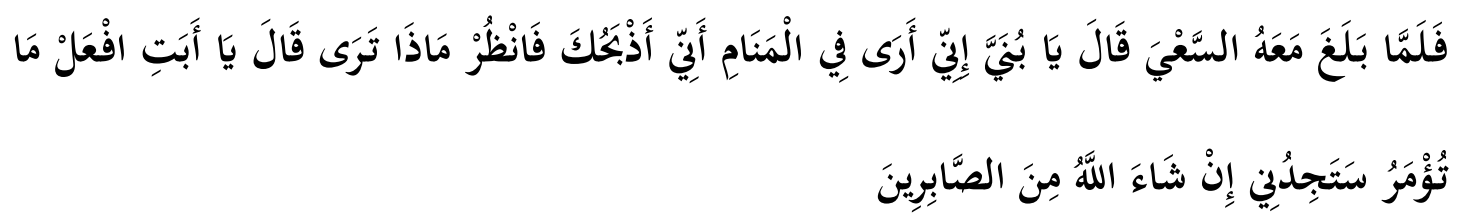

Terjemahnya:"Maka tatkala anak itu sampai (pada umur sanggup) berusaha bersama-sama Ibrahim, Ibrahim berkata: "Hai anakku sesungguhnya aku melihat dalam mimpi bahwa aku menyembelihmu. Maka fikirkanlah apa pendapatmu!" Ia menjawab: "Hai bapakku, kerjakanlah apa yang diperintahkan kepadamu; insya Allah kamu akan mendapatiku termasuk orang-orang yang sabar".(Q.S.Asshafaat: 102$)^{29}$

Remaja adalah fase produktif, semangat mencari ilmu, fase memperoleh kebahagiaan, tanggung jawab keagamaan. Pada fase ini remaja digolongkan menjadi manusia yang sudah diberi beban melaksanakan perintah Allah. Dia sudah mempunyai kesadaran penuh tentang Tuhan, dan condong kearah syahwat dengan prubahan fisik yang dimilikinya.

3. Fase Dewasa

Orang dewasa adalah usia yang memiliki kemantapan jiwa ,tanggung jawab serta menyadari makna hidup. Dengan kata lain , orang dewasa sudah memahami nilai-nilai yang dipilihnya dan berusaha untuk mempertahankannya nilai-nilai yang dipilihnya. Orang dewasa sudah memiliki identitas yang jelas dengan kepribadian yang mantap . usia dewasa biasanya memiliki sifat-sifat kepribadian yang stabil . stabilitas sifat-sifat kepribadian ini antara lain terlihat dari cara bertindak dan bertingkah laku yang tetap tanpa berubah-ubah dan selalu bersifat kembali.

Salah seorang tokoh Psikologi perkembangan Islam Salisu Shehu menyusun prinsip dasar psikologi perkembangan dari persfektif Islam yang terdiri dari kehidupan manusia, bahwa pertumbuhan dan perkembangan adalah salah satu proses yang gradual yang selalu melewati periode krisis dan dan sensitif tertentu .

${ }^{29}$ Ibid, ... 
kesimpulan tentang kehidupan manusia baik perkembangan maupun pertumbuhan adalah merupakan proses yang bertahap dan berangsur-angsur, sebagaimana telah disandarkan pada ayat Al-Qur'an surat al-insyiqaaq ayat 16-19,yaitu: ${ }^{30}$

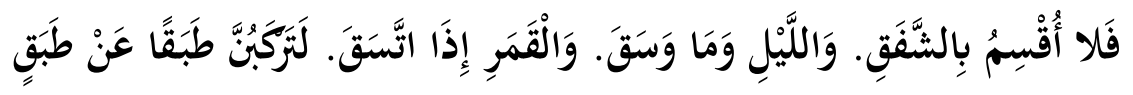

Terjemahnya:" Maka sesungguhnya Aku bersumpah dengan cahaya merah di waktu senja, dan dengan malam dan apa yang diselubunginya, dan dengan bulan apabila jadi purnama, sesungguhnya kamu melalui tingkat demi tingkat (dalam kehidupan)."

(Q.S.Al-Insyiqaq: 16-19)

Tingkat yang maksud disini ialah dari setetes air mani sampai dilahirkan , kemudian masa kanak-kanak, remaja dan sampai dewasa . dari hidup menjadi mati kemudian dibangkitkan lagi. Psikologi perkembangan dalam Islam merupakan kajian atas proses pertumbuhan dan perubahan manusia yang menjadikan Al-qur'an dan Hadits sebagai landasan pikirannya.Psikologi perkembangan dalam islam adalah perkembangan manusia tersebut meliputi proses pertumbuhan atau perubahan manusia serta membahas berbagai aspek perkembangan yang meliputi: aspek perkembangan fisik, kognitif, emosional, moral, social, spiritual, dan lain-lain.

Perkembangan disini di artikan sebagai perubahan yang dialami oleh individu atau organisme menuju tingkat kedewasaannya (matury) yang berlangsung secara sistematis, progresif, dan berkesinambungan baik fisik maupun psikis.

Para ahli psikologi perkembangan yang membahas mengenai perkembangan manusia selalu mengaitkan istilah nature (faktor alamiah) dan nurture (factor-faktor yang berhubungan dengan lingkungan) .Dimana setiap perkembangan manusia dipengaruhi oleh interaksi dari kedua hal tersebut. ${ }^{31}$

Perkembangan kognitif seseorang dilandasi oleh beberpa faktor- faktor yang sangat mendasari, adapun faktor-faktor tersebut yaitu: ${ }^{32}$

${ }^{30}$ Aliah B Purwakania Hasan,Psikologi Perkembangan Islami, (Jakarta: Grafindo, 2008), 23.

${ }^{31} \mathrm{Ibid}, 27$.

${ }^{32}$ Aliah B. Purwakania Hasan, 40. 
197 | MUSA WA, Vol. 13 No.2 Desember 2021 : 170-202

1. Faktor Hereditas dalam perkembangan.

Faktor hereditas merupakan faktor pertama yang mempengaruhi perkembangan individu. Hereditas diartikan sebagai totalitas karakteristik individu yang diwariskan orang tua kepada anak atau segala potensi, baik fisik maupun psikis yang dimiliki individu sejak masa konsepsi ( pembuahan ovum oleh sperma ) sebagai pewarisan dari pihak orang tua melalui gen - gen.

Para ahli Psikologi perkembangan mengakui bahwa aspek fisik maupun psikis seorang individu sangat dipengaruhi oleh unsur genetis, karakteristik tersebut akan nampak pada hal-hal sebagai berikut :

a) Sifat- sifat Fisik

Sifat-sifat fisik yang dapat diturunkan secara genetis misalnya wajah, tangan, kaki atau bagian-bagian organ tubuh lainnya.Hal ini dapat terjadi pada anak tunggal maupun kembar. Bila orang tua memiliki suatu jenis penyakit tertentu seperti: tekanan darah tinggi, penyakit jantung, epilepsi, atau paru-paru, kemungkinan besar anak-anak yang dilahirkan pun mempunyai resiko terserang penyakit yang sama.

b) Intelegensi

Kecerdasan yang dimilki orang tua akan dapat menurun pada anak-anaknya. Meskipun anak-anak tersebut diasuh oleh orang tuanya sendiri maupun oleh orang lain, sifat kecerdasan orang tua akan tetap menurun

c) Kepribadian

Kepribadian merupakan organisasi dinamis dari aspek fisiologis, kognitif maupun afektif yang membantu pola prilaku individu dalam rangka menyesuaikan diri dengan lingkungan hidupnya. Sebagai organisasi yang dinamis, maka kepribadian akan mempengaruhi perubahan pola pemikiran, sikap, dan perilaku seseorang.Sifat-sifat emosionil seperti perasaan takut, kemauan dan temperamen lebih banyak dipengaruhi oleh lingkungan dibandingkan dengan hereditas.

2. Pengaruh Lingkungan Dalam Perkembangan

Lingkungan memiliki peran yang besar bagi perubahan yang positif atau negatif pada individu. Lingkungan yang baik tentu akan membawa pengaruh positif 
bagi individu, sebaliknya lingkungan yang kurang baik akan cenderung memperburuk perkembangan individu dalam bentuk metaforik, dalam ajaran Islam telah diajarkan bahwa perbuatan yang baik dapat mempengaruhi karakter seseorang menjadi baik dan bagaimana teman yang jahat dapat membuat orang melakukan hal yang buruk.Dengan demikian, lingkungan dapat mempengaruhi keseluruhan perkembangan psikologi seseorang termasuk tentunya perkembangan kognitif.

\section{Pengaruh Ketentuan Allah SWT Dalam Perkembangan}

Terdapat bukti substansial yang memperlihatkan bahwa hereditas dan lingkungan semata-mata tidak dengan sendirinya menentukan pola perkembangan individu ada hal yang paling utama dalam persoalan tersebut yaitu segalanya tergantung kehendak Allah SWT.

Contoh yang paling mencolok adalah riwayat Nabi Isa A.S Ibn Maryam Allah SWT membuatnya dapat berbicara dalam buaiannya.Sebagaimana kita ketahui, perkembangan bahasa merupakan bagian integral dari perkembangan kognitif. Dalam situasi normal, anak mulai berbicara pada usia 2 tahun dalam sepatah dua patah kata dan sejalan dengan itu, mereka mulai mengembangkan perbendaharaan bahasa. Kenyataannya bahwa Nabi Isa AS dapat berbicara pada masa buaian, juga bukan produk stimulasi intelektual dari lingkungan.

Hal tersebut lebih merupakan manifestasi dari kebijaksanaan Tuhan, kekuatanNya yang tidak terbatas, KehendakNya dan kemampuanNya untuk melakukan segala sesuatu.Al-Qur'an menceritakan kejadian ini dalam beberapa ayat. Pertama Al-Qur' an menceritakan bagaimana Maryam diberitahu bahwa anaknya akan berbicara sejak dalam buaian. Ayat ini berbunyi :

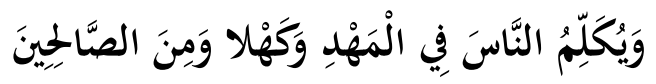

Terjemahnya :" dan dia berkata kepada manusia dalam buaian dan ketika sudah dewasa, dia adalah salah seorang diantara orang-orang yang shaleh.” (QS. Ali-Imran : 46) 
199 | MUSA WA, Vol. 13 No.2 Desember 2021 : 170-202

Meskipun hereditas dan lingkungan merupakan faktor yang tak dapat diragukan mempengaruhi perkembangan manusia, ada faktor ketiga yang lebih signifikan dan dominan yaitu kehendak dan kekuatan Allah SWT yang tidak terbatas. Faktor inilah yang memantau dan menjaga besarnya kekuatan alam dan pengasuhan yang mempengaruhi kehidupan dan perkembangan manusia. Hal ini dapat diterapkan pada semua aspek perkembangan. Contohnya, perkembangan kognitif bukan sematamata produk warisan genetik, ataupun semata-mata produk lingkungan, sebab pada prinsipnya, ia merupakan produk kehendak dan kekuatan Allah SWT. Sehubungan dengan hal ini, hereditas dan kekuatan lingkungan merupakan media yang menunjukkan bahwa Allah SWT memperlihatkan kecenderungan pola dari perkembangan individu.Dengan demikian, kedua faktor ini memiliki batasan dalam mempengaruhi kecenderungan psikologi seseorang secara keseluruhan.Batasan tersebut telah ditentukan oleh Allah SWT.

Kajian psikologi, faktor ini merupakan hal yang penting untuk diperhatikan karena banyak hal yang terjadi dalam kehidupan manusia yang tidak dapat digolongkan ke dalam faktor hereditas atau lingkungan (seperti contoh diatas).Dengan demikian, hal tersebut tidak dapat diterangkan dalam keranda penyelidikan material atau empirik. Jika psikolog tidak memperluas horizon dalam hal ini pendekatan mereka dengan meneliti faktor kehendak dan kekuasaan Allah SWT diatas segalanya, termasuk perkembangan psikologi manusia, akan tetap tidak lengkap dan pengetahuan tentang diri kita juga masih tetap tidak utuh.

Peran kehendak Allah SWT dalam menentukan perkembangan individual seperti yang dinyatakan dalam pendekatan Islam akan membantu memahami proses perkembangan yang lebih baik dari pada pendekatan psikologi Barat dengan berbagai cara. Perlu disadari bahwa, tidak semua konstruk dan kecenderungan psikologi dapat secara ketat dipengaruhi oleh semata-mata pengaruh herediter dan lingkungan karena bagaimanapun individu kadang-kadang menunjukkan kecenderungan tertentu yang secara jelas menyimpang dari penjelasan pengaruh hereditas dan lingkungan.Kasus kemampuan bicara Nabi Isa AS dan lainnya dalam buaian adalah kesaksian terhadap 
hal ini.Dalam hal ini, jika tidak diatribusikan kepada kehendak Allah SWT, hanya kebohongan yang merupakan penjelasan fakta ini.

Setiap perkembangan meningkatkan satu aspek dengan dasar peningkatan sebelumnya sampai pencapaian tahap puncak. Alquran juga mengajarkan bahwa perkembangan manusia merupakan proses simultan dari aspek-aspek yang berhubungan . hal ini berarti segala aspek perkembangan fisik, mental, sosial, emosional, dan moral tidak dapat dipisahkan satu sama lainnya. Masing-masing saling mendukung dan menguatkan.

Maka jelaslah, hidup ini penuh dengan ketentuan Illahi.Terutama tampak nyata pada awal kelahiran seseorang. Sebagian beruntung karena memiliki kecerdasan yang istimewa, sementara yang lain hidup dalam keadaan serba kurang keduanya sama saja mempunyai akibat dari perkembangannya, tetapi apa hendak di kata, semua ini telah menjadi kodrat Illahi. Walhasil, perkembangan ini pada azasnya berpangkal pada kodrat Illahi atas setiap manusia.Karenanya di atas kodrat itulah sesungguhnya perkembanganya berlangsung.

\section{Kesimpulan}

Berdasarkan dari uraian di atas tersebut penulis dapat disimpulkan sebagai berikut, yaitu:

1. Perkembangan anak dalam tinjauan teori kognitif dapat dilihat dan di pelajari dari sisi kemampuan kognisi, seperti: Persepsi, proses belajar, kemampuan memori, atensi, kemampuan bahasa dan emosi. Pendekatan kognitif menekankan bahwa tingkah laku adalah proses mental, dimana individu (organisme) aktif dalam menangkap, menilai, membandingkan, dan menanggapi stimulus sebelum melakukan reaksi. Individu menerima stimulus lalu melakukan proses mental sebelum memberikan reaksi atas stimulus yang datang.Namun disisi yang lain ada juga yang berpendapat Psikologi kognitif adalah kajian studi ilmiah mengenai proses-proses mental atau pikiran. Proses 
201 | MUSA WA, Vol. 13 No.2 Desember 2021 : 170-202

ini meliputi bagaimana informasi diperoleh, dipresentasikan dan ditransfermasikan sebagai pengetahuan. Pengetahuan itu dimunculkan kembali sebagai petunjuk dalam sikap dan perilaku manusia. Oleh karena itu, psikologi kognitif juga disebut psikologi pemrosesan informasi. Adapun fase perkembangan kognitif menjadi empat perkembangan yaitu, tingkat sensori matorik,tingkat preoperasional, tingkat operasi konkret,dan tingkat operasi formal.

2. Perkembangan kognitif Anak sangat di pengaruhi oleh lingkungan keluarga oleh karena setiap tahapan perkembangan keluarga selalu hadir di dalamnya misalnya mengenai tahap-tahap perkembangan pribadi serta perubahan umur yang mempengaruhi kemampuan belajar individu maupun perkembangan intelegensinya atau proses berpikir. Pertumbuhan kapasitas mental anak memberikan kemampuan-kemampuan mental baru yang sebelumya tidak ada.

3. Perkembangan kognitif Anak dalam Persfektif Pendidikan Islam menunjukan. Agama Islam berisi pedoman bagi manusia yang berakal. Hanya manusia yang berakal saja yang dapat mengambil pelajaran dari penciptaan langit dan bumi.Pembinaan pola pikir/kognitif, yakni pembinaan kecerdasan dan ilmu pengetahuan yang luas dan mendalam sebagai penjabaran dari sifat fathonah Rosulullah. Merujuk kepada informasi al-Qur'an pendidikan mencakup segala aspek jagat raya ini, bukan hanya terbatas pada manusia semata, yakni dengan menempatkan Allah sebagai Pendidik Yang Maha Agung. Konsep pendidikan al-Qur'an sejalan dengan konsep pendidikan Islam yang dipresentasikan melalui kata tarbiyah, ta'lim dan ta'dib. Dalam mengenbangkan kognitif dipengaruhi oleh tiga faktor yaitu: faktor hereditas dalam perkembangan, faktor lingkungan dalam perkembangan,dan faktor pengaruh atas ketentuan Allah swt dalam perkembangan. 
Suharnis, Perkembangan Kognitif ... | 202

\section{DAFTAR PUSTAKA}

Ali, Moh. Daud, Pendidikan Agama Islam, Jakarta: Raja Grafindo, Persada, 2010.

Bukhari, Umar, Ilmu Pendidikan Islam, Jakarta: Amzah, 2011.

Dalyono, M. Psikologi Pendidikan, Jakarta: Rineka Cipta, 2010.

Daradjat, Zakiah, Pendidikan Islam dalam Keluarga dan sekolah, Bandung; Rosdakarya, 1995.

Djaali, Psikologi Pendidikan, Jakarta: Bumi Aksara, 2009.

Hasan, Purwakania, Aliah, Psikologi Perkembangan Islami, Jakarta: Grafindo, 2008.

http://www.pak-sodikin.com/2011/12/9-ciri-ciri-dan-karakteristik-manusia.html. diakses 12 Februari 2013.

Karim, Malik, Amrullah, Jurnal Psikologi Vol.V. No. 1. Fase Motif Beragama Menurut Islam. Malang; Universitas Islam Negeri Malang Press, 2008, No. 3.

Suparno, Paul. Perkembangan Kognitif Jean Piaget, Yogyakarta: Kanisius, 2006.

Syah, Muhibbin, Psikologi Pendidikan dengan Pendekatan Baru, Bandung: PT Remaja Rosdakarya, 2002.

Tim Penerbit Erlangga, Perkembangan Anak Edisi 20, Jakarta: Erlangga, 2007.

Uno, Hamzah B, Orientasi Baru Dalam Psikologi Pembelajaran, Jakarta; Bumi Aksara, 2006.

Zahrudin, dkk, Pengantar Studi Akhlak, Jakarta: Grafindo, 2004. 